\title{
The influence of plant addition to some physicochemical, textural, microstructural, melting ability and sensory properties of Mozzarella cheese
}

\author{
Oktay Yerlikaya ${ }^{1 *}$,Ecem Akan ${ }^{1,2}$, Ozge Yildiz Bayram³, \\ Ayse Demet Karaman², Ozer Kinik
}

\begin{abstract}
'Ege University, Faculty of Agriculture, Department of Dairy Technology, Bornova, Izmir Turkey ${ }^{2}$ Aydin Adnan Menderes University, Faculty of Agriculture, Department of Dairy Technology, Koçarli, Aydin, Turkey

${ }^{3}$ Aegean Agricultural Research Institute, Technology Laboratory, Menemen, Izmir, Turkey

${ }^{*}$ Corresponding author: oktay.yerlikaya@ege.edu.tr
\end{abstract}

\section{Abstract}

Mozzarella cheese is produced by kneading the curd, which has a fibrous structure with melting and elongation properties, in hot water. The present study aimed to investigate the impact of the addition of some plants on certain properties of Mozzarella cheese. Rosemary (Rosmarinus officinalis L.), basil (Ocimum basilicum L.), mint (Mentha piperita L.) and Turkish Oregano (Origanum onites L.) were added to Mozzarella cheese at the curd kneading stage, and physicochemical, textural, microstructural, meltability and sensory properties were investigated during the storage period. No plants were added to the control group cheese. Plant addition to Mozzarella cheese affected some physicochemical properties such as pH, acidity, free fatty acids, as well as textural and microstructural properties. Furthermore, it affected sensory properties, especially Turkish Oregano and mint addition provided high general acceptability and taste-aroma scores. While higher $\mathrm{pH}$ and lower titration acidity were determined in rosemary-added cheese samples, the lowest free fatty acid (ADV) levels were determined in the mint-added cheese sample. Rosemary-added cheeses had higher hardness and a more even microstructure, while the highest sensory scores were obstained for cheeses that included Turkish Oregano and mint. In conclusion, the present study findings demonstrated that the short shelf life of Mozzarella cheese could be extended with the addition of various plants due to their effects on $\mathrm{pH}$, acidity and free fatty acids.

Key words: Mozzarella, plants, microstructure, meltability, fresh cheeses 


\section{Introduction}

Cheese is an easily digestible dairy product rich in fat, protein, calcium, vitamins $A$ and $B_{2}$ with a long shelf life and included in the daily diet of individuals in all walks of life (Renner, 1993; Walter et al., 2008). Fats, insoluble salts and colloidal substance content of milk, which is generally used in cheese production, are the main contents of cheese. Also, proteins, soluble salts, vitamins, and other nutrients in milk serum are included in the composition of cheese to a certain extent (Scott, 1986; Walstra et al., 1999).

Mozzarella cheese, a semi-hard cheese, is a fresh cheese with fibre content. Fibrous elongated type cheeses acquire the fibrous structure, melting and elongation properties by boiling, shaping and kneading the fresh clot in hot water. Mozzarella cheese is traditionally produced from buffalo milk and consumed fresh. However, due to the insufficient global buffalo milk production, cow milk is preferred by most producers. Mozzarella cheese was first produced in Italy. Mozzarella cheese, which is used in several dishes and especially in pizza, is also commonly used in salads and breakfast. The four varieties include Mozzarella di Bufala, Mozzarella Fior di Latte, Low-fat Mozzarella and Smoked Mozzarella. Mozzarella is mostly spherical and egg-shaped, $10-15 \mathrm{~cm}$ in diameter and weighs 125-350 g and served in slices (Kindstedt, 1993; Tunick and Shieh, 1995; Fife et al., 1996; Anonymous, 2020).

Plants are used for the enrichment of several dairy products due to their bioactive components. The World Health Organization (WHO) estimated that $80 \%$ of the global population employ medicinal plants for healing. The growing interest in medicinal plants also increased the interest of the pharmacology industry in these plants. Recent studies demonstrated that medicinal plants play an important role in the treatment of several diseases. Due to their health benefits, the potential for research on plants has been increasing (Khajoei Nasab et al., 2014; Atanasov et al., 2015; Mustafa et al., 2017; Aćimović et al., 2019).

Since plants have several functional properties such as antioxidant and antimicrobial capacity, their usage has increased in the food industry. The most prevalent medicinal and aromatic plants are
Turkish Oregano, sage, savoury and mint. Due to its large surface area, the plant diversity is quite high in Turkey and medicinal and aromatic plant cultivation has a significant potential throughout the different climate regimes in the country. Due to their important bioactive components, Turkish Oregano, peppermint, rosemary and basil, which are medicinal and aromatic plants, have been widely used in research (Koç et al., 2018; Sezen et al., 2018). The addition of plants and their essential oils to cheeses prevents the development of pathogenic and spoiling microorganisms and could have a positive effect on cheese quality (Puvača et al., 2020).

Today, addition of certain plants to food products is more prevalent. Thus, there is an increased interest in taste-aroma, flavour and preservation of plants and their extracts into food products. The purpose of addition of plants and/or plant extracts to cheese is to provide a different flavour, taste-aroma, improve the shelf life, and promote cheese consumption. In the present study, certain plants were added to Mozzarella cheese during production and their effects on certain cheese properties were investigated. It could be suggested that studies on the use of plants in food production would increase. Plant supplements would extend the shelf life of the Mozzarella cheese, and the product would achieve a different flavour. This study aimed to determine some physicochemical, rheological, microstructural, meltability and sensory properties of Mozzarella cheese produced with certain highly consumed and flavoured herbs such as rosemary (Rosmarinus officinalis L.), basil (Ocimum basilicum L.), mint (Mentha piperita L.), and Turkish Oregano (Origanum onites L.).

\section{Material and method}

\section{Material}

Lyophilized thermophilic cheese culture containing Streptococcus thermophilus, Lactobacillus debrueckii subsp. bulgaricus, Lactobacillus helveticus bacteria and rennin enzyme (chymosin) (1/15.000 strength) (TSI Inc. Lakeville, USA) were obtained from Mayasan Gıda Sanayi ve Ticaret A.Ş. (Yenibosna, Istanbul). Determination of rennin strength and rennin addition rate to milk was determined based on the method proposed by Ucuncu (2004). 
The salt was obtained from Billur Tuz (Cigli, İzmir, Turkey). Rosemary (Rosmarinus officinalis L.), basil (Ocimum basilicum L.), mint (Mentha piperita L.) and Turkish Oregano (Origanum onites L.) were prepared for use in post-boiling kneading and procured from Kimbiyotek (Basaksehir, Istanbul, Turkey).

\section{Method}

\section{PRODUCTION OF MOZZARELLA CHEESE}

The raw milk was heated between 68 and $71^{\circ} \mathrm{C}$ for 5 minutes and then cooled to $35-37^{\circ} \mathrm{C}$, and then calcium chloride $\left(0.02 \% \mathrm{CaCl}_{2}\right)$ and 0.5 $\%$ active thermophilic culture were added. After acidification for approximately 45 minutes, the acidity of milk was increased to around $9{ }^{\circ} \mathrm{SH}$ by adding 10-20 mL rennet per $100 \mathrm{~mL}$ milk at 35 ${ }^{\circ} \mathrm{C}$, and the fermented milk was coagulated for 30 45 minutes to acquire cutting maturity. The curd product was cut into $10-15 \mathrm{~mm}$ pieces, allowed to rest for 5-10 minutes, then stirred slowly for 5 minutes, then the curd pile was pressed lightly and kept hot for fermentation. During this period, the $\mathrm{pH}$ value was kept at 5.1-5.2. After this stage, the cheese water in the process tank was slowly discharged, when adequate acidity developed for curd pressing and fusing, it was taken from the curing cloths and cut into small slices. Curd was then put in boiling water at a temperature of $75-82{ }^{\circ} \mathrm{C}$ and kneaded by stretching it in the form of a thick rope. Herbs were added during the post-boiling kneading at about $0.5 \%$ (w/w) of the curd content (Table 1). In the following stage, the curd dough was divided into portions and shaped by rolling, and hardened by cooling for 15-30 minutes at $10^{\circ} \mathrm{C}$. The cheese products were kept in brine with a $-6 \%$ salt ratio and when salting was

TABLE 1. Mozzarella cheese types and cheese codes

\begin{tabular}{l|l}
\hline Mozzarella cheese types & Cheese codes \\
\hline Mozzarella cheese (without plants) & C \\
\hline Mozzarella cheese (with rosemary) & $\mathrm{R}$ \\
\hline Mozzarella cheese (with basil) & $\mathrm{B}$ \\
\hline Mozzarella cheese (with mint) & $\mathrm{M}$ \\
\hline Mozzarella cheese (with Turkish Oregano) & $\mathrm{T}$ \\
\hline
\end{tabular}

complete, they were removed from the brine and allowed to drain for 2-6 hours. The cheese products were stored for 30 days at $4{ }^{\circ} \mathrm{C}$ in cold storage $\left(+4{ }^{\circ} \mathrm{C}\right)$.

\section{ANALYSIS METHOD}

Sampling for the analysis of milk and cheese products was conducted based on the International Dairy Federation procedures (IDF, 1980). The study was conducted with two repetitions, and all analyses were conducted in three replicates.

\section{Physicochemical properties of cheese products}

Total dry matter content in Mozzarella cheese products was determined with the gravimetric method (ISO, 2004), the fat ratio was determined with the Gerber method (ISO, 2008), salt ratios were determined with titration of the sample prepared based on the Mohr titration method with 0.1 $\mathrm{N} \mathrm{AgNO}_{3}$ (Kirk and Sawyer, 1991). Electrode digital pH-meter (Hanna HI 83141, Hanna Instruments, Romania) was used in $\mathrm{pH}$ measurements (Kosikowski, 1982). Titratable acidity / Lactic acid \% was determined using a $10 \mathrm{~g}$ cheese sample with $0.1 \mathrm{~N} \mathrm{NaOH}$ and titration up to $8.3 \mathrm{pH}$ (AOAC, 1990). Total nitrogen and protein content were determined with the Kjeldahl method, and the protein ratio was calculated by multiplying the nitrogen amount by the multiplication factor of 6.38 (Ardö, 1999). The acid degree value (ADV) that indicate the free fatty acid content was determined with the method reported by Renner (1993) and the results are presented as $\mathrm{mg} \mathrm{KOH}$ equivalent/100 g

\section{Rheological properties of cheese products}

\section{TEXTURE PROFILE ANALYSIS (TPA)}

The texture profile analysis of the cheese samples was conducted with a Texture Analyzer (Texture Analyzer CT3, Brookfield, USA) and hardness (g), adhesiveness (g), springiness ( $\mathrm{mm}$ ), gumminess (g) and chewiness $(\mathrm{mJ})$ parameters were determined on the $1^{\text {st }}$ and $30^{\text {th }}$ day of storage as described by Stevens and Shah (2002). Cheese samples were cut properly in $1 \mathrm{~cm}^{3}$ blocks before the analysis. Measurement parameters were calculated with Brookfield Texture Pro CT software. A two-bite penetration test was 
conducted with a TA4/1000 (38.1 mm diameter-20 $\mathrm{mm}$ height) and operated at a crosshead speed of 1 $\mathrm{mm} / \mathrm{s}$ (50\% pressure) in a downward direction with 2 seconds between the two cycles.

\section{Microstructural analysis of cheese products}

Microstructural properties of Mozzarella cheeses were determined on the $1^{\text {st }}$ production. Cheese samples were cut in 4-5 $\mathrm{mm}^{3}$ pieces and kept in $2.8 \%(\mathrm{w} / \mathrm{v})$ glutaraldehyde solution for fixation (Sigma-Aldrich, St. Louis, USA) for one night. Then, the cheese samples were washed with distilled water and this process was repeated three times. After two 30- and 60-minute fixations, the samples were stored in 20, 40, 60, 80, 95 and $100 \%$ ethanol solutions (Merck, Darmstadt, Germany) for not less than 2 hours. Then, the fat was extracted from the samples with a chloroform solution in 15-minute intervals. The samples were stored at $-18^{\circ} \mathrm{C}$ until the analysis (Sipahioglu et al., 1999). The status of the samples in the cheese matrix were determined with a Hitachi TV1000 TableTop Microscope (Japan).

\section{Melting ability of cheese products}

The melting ability of cheese samples was determined with the Schreiber melting test. Schreiber melting test was applied as follows: The cheese discs with a $17 \mathrm{~mm}$ diameter and $5 \mathrm{~mm}$ thickness were prepared and covered with aluminium foil and stored at $5{ }^{\circ} \mathrm{C}$ for one night. Each disc was placed in the middle of a petri dish and heated up to $100^{\circ} \mathrm{C}$ in the oven for 5 minutes, then cooled to room temperature on a flat surface. The measurements were conducted on 6 points at a distance with equal angle intervals from the center and the mean value was calculated (Park et al. 1984; Wang and Sun, 2002)

\section{Sensory evaluation of cheese products}

The scoring test (Table 2) was used in the sensory evaluation of the cheese samples. The scoring test was conducted with a semi-trained panellist group that included 6 faculty members in Ege University, Department of Dairy Technology. Samples were evaluated in detail on the $1^{\text {st }}, 10^{\text {th }}, 20^{\text {th }}$ and $30^{\text {th }}$ days of storage based on appearance, consistency,
TABLE 2. Sensory evaluation scale for scoring

\begin{tabular}{l|l|l|l}
\hline \multicolumn{4}{l}{ Rating scale about likes } \\
\hline Excellent & 9 points & Below average & 4 points \\
\hline Very Good & 8 points & Bad & 3 points \\
\hline Good & 7 points & Very bad & 2 points \\
\hline $\begin{array}{l}\text { Good under } \\
\text { medium }\end{array}$ & 6 points & $\begin{array}{l}\text { Excessively } \\
\text { bad }\end{array}$ & 1 point \\
\hline Medium & 5 points & & \\
\hline
\end{tabular}

smell, flavour and overall acceptance (highest score: 9, lowest score: 1). Cheese samples were coded using different letters for the panellists and samples were presented at $+4{ }^{\circ} \mathrm{C}$. Panellists were asked to score sensory perceptions on the evaluation form organized based on the Table 2 (Andreatta et al., 2009; Wichchukit and O'Mahony, 2015). Sensory data were normalized before statistical analysis and ANOVA repeated measurement procedure was conducted.

\section{Statistical analysis}

The study was conducted in two repetitions and the analyses were carried out in three parallels. The statistical analysis findings are presented with mean and standard deviation figures, and one-way analysis of variance (ANOVA) and the DUNCAN test were conducted in SPSS version 20.0 (SPSS Inc. Chicago, Illinois) software. $P<0.05$ was accepted as statistical significance level.

\section{Results and discussion}

\section{Physicochemical properties of Mozzarella cheese}

Mozzarella cheese curd (dry matter: $42.87 \%$; fat: $22.50 \%$; protein: $17.50 \%$; lactose: $1.60 \%$; ash: $0.98 \%$, titratable acidity (lactic acid \%): 0.30, pH: 6.05) was used in the production of plant added Mozzarella cheese products. Physicochemical properties of Mozzarella cheese samples with plant supplements are presented in Table 3. The dry matter content is important for the cheese packaged in both brine and vacuum to retain the desired 
TABLE 3. Average physicochemical properties of Mozzarella cheeses $(n=2)$

\begin{tabular}{l|l|l|l|l|l|l}
\hline Samples & Dry matter (\%) & Fat \% & Salt $(\mathrm{NaCl}) \%$ & Protein \% & Fat in dry matter (\%) & Salt in dry matter (\%) \\
\hline $\mathrm{C}$ & $39.10 \pm 0.51$ & $11.5 \pm 0.05$ & $5.55 \pm 0.08$ & $18.87 \pm 1.04$ & $29.11 \pm 1.24$ & $14.19 \pm 1.50$ \\
\hline $\mathrm{R}$ & $39.30 \pm 0.06$ & $11.5 \pm 0.05$ & $5.96 \pm 0.04$ & $19.94 \pm 1.09$ & $29.26 \pm 1.85$ & $15.16 \pm 1.42$ \\
\hline $\mathrm{B}$ & $46.84 \pm 0.97$ & $12.00 \pm 0.05$ & $5.21 \pm 0.08$ & $21.52 \pm 0.81$ & $25.61 \pm 1.24$ & $11.12 \pm 1.50$ \\
\hline $\mathrm{M}$ & $41.44 \pm 0.72$ & $13.5 \pm 0.05$ & $5.72 \pm 0.02$ & $19.73 \pm 0.78$ & $32.57 \pm 0.85$ & $13.80 \pm 0.90$ \\
\hline $\mathrm{T}$ & $41.23 \pm 0.43$ & $14.00 \pm 0.05$ & $4.38 \pm 0.02$ & $20.58 \pm 1.09$ & $33.95 \pm 0.89$ & $10.62 \pm 0.75$ \\
\hline
\end{tabular}

C: Plant-free Mozzarella cheese, R: Rosemary-added Mozzarella cheese, B: Basil-added Mozzarella cheese, M: Mint-added Mozzarella cheese, T: Turkish Oregano-added Mozzarella cheese

TABLE 4. $\mathrm{pH}$, titration acidity and free fatty acid value (ADV) changes in the storage process of Mozzarella cheeses ( $\mathrm{n}=2)$

\begin{tabular}{|c|c|c|c|c|}
\hline \multirow[b]{2}{*}{ Samples } & \multicolumn{4}{|c|}{$\mathrm{pH}$} \\
\hline & 1 & 10 & 20 & 30 \\
\hline C & $5.48 \pm 0.03^{B}$ & $5.49 \pm 0.03^{B}$ & $5.59 \pm 0.00^{A}$ & $5.50 \pm 0.01^{\mathrm{B}}$ \\
\hline $\mathrm{R}$ & $5.53 \pm 0.01^{A}$ & $5.64 \pm 0.02^{A}$ & $5.59 \pm 0.01^{\mathrm{A}}$ & $5.58 \pm 0.04^{A}$ \\
\hline B & $5.48 \pm 0.03^{B}$ & $5.57 \pm 0.04^{\mathrm{AB}}$ & $5.57 \pm 0.01^{\mathrm{A}}$ & $5.51 \pm 0.02^{\mathrm{B}}$ \\
\hline M & $5.45 \pm 0.02^{B}$ & $5.49 \pm 0.03^{B}$ & $5.51 \pm 0.02^{B}$ & $5.50 \pm 0.01^{\mathrm{B}}$ \\
\hline \multirow[t]{2}{*}{ T } & $5.47 \pm 0.02^{B}$ & $5.53 \pm 0.00^{\mathrm{B}}$ & $5.55 \pm 0.03^{B}$ & $5.48 \pm 0.02^{\mathrm{B}}$ \\
\hline & \multicolumn{4}{|c|}{ Titratable acidity (Lactic acid \%) } \\
\hline C & $1.18 \pm 0.04^{B}$ & $1.41 \pm 0.00^{B}$ & $1.44 \pm 0.00^{\mathrm{B}}$ & $1.16 \pm 0.01^{B C}$ \\
\hline $\mathrm{R}$ & $0.86 \pm 0.05^{D}$ & $1.11 \pm 0.09^{D}$ & $1.03 \pm 0.00^{c}$ & $0.91 \pm 0.02^{c}$ \\
\hline B & $1.09 \pm 0.11^{c}$ & $1.25 \pm 0.03^{c}$ & $1.37 \pm 0.05^{\mathrm{B}}$ & $1.16 \pm 0.01^{B C}$ \\
\hline M & $1.26 \pm 0.02^{A}$ & $1.65 \pm 0.06^{A}$ & $1.46 \pm 0.04^{\mathrm{A}}$ & $1.21 \pm 0.01^{\mathrm{B}}$ \\
\hline \multirow[t]{2}{*}{ T } & $1.28 \pm 0.02^{A}$ & $1.45 \pm 0.02^{B}$ & $1.36 \pm 0.03^{B}$ & $1.39 \pm 0.07^{A}$ \\
\hline & \multicolumn{4}{|c|}{ Free fatty acid value, ADV (mg KOH per $100 \mathrm{~g}$ ) } \\
\hline C & $0.85 \pm 0.34^{A}$ & $1.23 \pm 0.85^{\mathrm{A}}$ & $2.85 \pm 0.54^{\mathrm{A}}$ & $3.25 \pm 0.86^{A}$ \\
\hline $\mathrm{R}$ & $0.79 \pm 0.18^{B}$ & $1.08 \pm 0.20^{\mathrm{B}}$ & $1.90 \pm 0.19^{\mathrm{B}}$ & $2.65 \pm 0.30^{B}$ \\
\hline B & $0.80 \pm 0.24^{\mathrm{AB}}$ & $0.96 \pm 0.38^{c}$ & $1.96 \pm 0.25^{\mathrm{B}}$ & $2.42 \pm 0.14^{c}$ \\
\hline M & $0.65 \pm 0.12^{c}$ & $0.86 \pm 0.21^{D}$ & $1.08 \pm 0.24^{\mathrm{D}}$ & $1.67 \pm 0.17^{D}$ \\
\hline T & $0.76 \pm 0.23^{B}$ & $0.90 \pm 0.18^{\mathrm{CD}}$ & $1.19 \pm 0.22^{c}$ & $1.78 \pm 0.56^{D}$ \\
\hline
\end{tabular}

C: Plant-free Mozzarella cheese, R: Rosemary-added Mozzarella cheese, B: Basil-added Mozzarella cheese, M: Mint-added Mozzarella cheese, T: Turkish Oregano-added Mozzarella cheese

$A, B, C, D, E T h e$ difference between values with different exponential expressions in the same column was statistically significant $(P<0.05)$

structure and sensory properties. Dry matter ratio of the cheese samples varied between $39.10 \%$ and $46.84 \%$, fat content varied between 11.50 and 14.00 $\%$, protein ratio varied between 18.87 and $21.52 \%$, and salinity varied between 4.38 and $5.96 \%$. The study findings were consistent with previous studies (Ozsuner, 2010; Rizgiati et al. 2016; Hamad et al. 2017; Fasale et al. 2017).
$\mathrm{pH}$

$\mathrm{pH}$ value is an important parameter to determine the shelf life and quality of the food product. $\mathrm{pH}$ measurements were conducted on the 30 days of storage and the findings are presented in Table 4. The $\mathrm{pH}$ variation is associated with the change in $\mathrm{H}^{+}$ concentration due to the organic acid production by 
the lactic acid bacteria. All cheese varieties initially had similar $\mathrm{pH}$ values during the storage period (ranged between 5.47 and 5.53). It was observed that the employment of different plants statistically $(\mathrm{P}<0.05)$ changed the $\mathrm{pH}$ of Mozzarella cheese. Based on the sample $\mathrm{pH}$ values, it could be suggested that the cheese products were adequate for consumption during the storage. As the measured $\mathrm{pH}$ values increased during storage, it could be suggested that the presence of the herbs did not negatively affect the metabolic bacteria activities in the maturation flora. There are different reports in the literature about the $\mathrm{pH}$ values of cheese that included plant extracts. In these studies, similar and contradictory findings were reported (Ozsuner, 2010; Rizgiati et al., 2016; Hamad et al., 2017; Fasale et al., 2017).

\section{Titratable acidity}

On the $1^{\text {st }}$ and $30^{\text {th }}$ day of the storage, titratable acidity of the Mozzarella cheese samples varied between 0.86 and 1.28, and between 0.91 and 1.39 , respectively (Table 4 ). The highest acidity was determined in the $T$ sample on the $30^{\text {th }}$ day of the storage, while the lowest value was determined in the R sample. In the present study, there were statistical differences between the titratable acidity of the samples $(P<0.05)$. The fluctuations in titratable acidity were observed in all cheese samples during the storage period. Several studies reported that the development of acidity in cheese was affected by factors such as the production technique, cheese variety, different plant extracts used in production, storage processes and the type of starter culture (Akarca et al., 2016: Rizqiati et al., 2016; Deveci, 2016).

Free fatty acid content (Acid Degree Value, ADV)

Lipolysis is the most important biochemical process that plays a role in the formation of flavor in cheese along with proteolysis. During the storage period, the changes in the free fatty acid content in Mozzarella cheese samples are presented in Table 4. In the present study, it was determined that $M$ and $T$ samples had lower ADV when compared to $C, R$ and $B$ samples during storage $(P<0.05)$. On the $1^{\text {st }}$ day of the storage ADV of C, R, B, M and T samples were determined as $0.85,0.79,0.80,0.65$ and $0.76 \mathrm{mg} \mathrm{KOH} / 100 \mathrm{~g}$, respectively, while on the $30^{\text {th }}$ day of storage, ADV values were determined as 3.25 ; $2.65 ; 2.42 ; 1.67 ; 1.78 \mathrm{mg} \mathrm{KOH/100} \mathrm{g,} \mathrm{re-}$ spectively. This could be explained by the effect of plant content on the lipase enzyme activity in Mozzarella cheese samples. It was also suggested that the lipase enzyme may be rendered inactive due to the prolonged scalding time of the curd during production.

In the current study, it was determined that different plants and storage periods had significant effects on free fatty acid content $(\mathrm{P}<0.05)$ except for the cheese with mint and Turkish Oregano supplements. During storage, free fatty acid content regularly increased in all samples. Yaygin and Dabiri (1989), Kocak et al. (1996), Yasar (1999) and Sahan et al. (2008) reported that the free fatty acid content increased in Kashar cheese during ripening. Omar and El-Zayad (1986) found that the concentration of fatty acids in Kashkaval cheese increased during ripening. Certain studies reported that free fatty acid content increased during ripening in Ras, Muenster, and Kefalograviera cheese, produced with different salting methods (Abou El-Ella et al., 1988; Gonzalez et al., 2000; Katsiari et al., 2001; Hamad et al., 2017). Agboola and Radovanovic-Tesic (2002) determined that the addition of certain plant flavors led to higher lipolysis levels in cheese. Andic et al. (2010) found that the acid degree value (ADV) varied between 1.61 and $13.32 \%$ in herby cheese samples procured in the market.

\section{Textural properties of Mozzarella cheese}

The texture is an important quality criterion, where the structural, mechanical and surface properties of the food are determined by observation, auditory, tactile and kinesthetic methods (Szczesniak, 2002). During storage, changes in physicochemical properties of the cheese are affected by textural properties. The increase in moisture content decreases hardness, while an increase in fat content increases springiness. Ozcan et al. (2017) reported that raw milk composition, raw milk processes, heat treatment process, $\mathrm{pH}$, type of the plant, salt, starter culture type effected the textural 
TABLE 5. Textural properties of Mozzarella cheese samples ( $n=2)$

\begin{tabular}{|c|c|c|c|c|c|c|}
\hline Samples & Storage days & Hardness (g) & Adhesiveness (g) & Springiness (mm) & Gumminess (g) & Chewiness (mJ) \\
\hline \multirow[t]{2}{*}{ C } & 1 & $960 \pm 7.07^{D}$ & $0.79 \pm 0.01^{\mathrm{B}}$ & $3.33 \pm 0.02^{c}$ & $327.3 \pm 1.48^{\mathrm{D}}$ & $11.11 \pm 0.16^{\mathrm{D}}$ \\
\hline & 30 & $403.5 \pm 4.95^{d}$ & $0.81 \pm 0.04^{c}$ & $3.52 \pm 0.01^{b}$ & $757.9 \pm 0.28^{d}$ & $26.6 \pm 0.85^{d}$ \\
\hline \multirow[t]{2}{*}{$\mathrm{R}$} & 1 & $357.5 \pm 3.54^{\mathrm{E}}$ & $0.82 \pm 0.00 \mathrm{~A}$ & $3.40 \pm 0.04 c$ & $264.6 \pm 0.42^{\mathrm{E}}$ & $8.93 \pm 0.04^{E}$ \\
\hline & 30 & $324.5 \pm 0.71^{\mathrm{Ee}}$ & $0.85 \pm 0.07^{b}$ & $3.44 \pm 0.03^{d}$ & $302.9 \pm 2.05^{e}$ & $10.84 \pm 0.04^{e}$ \\
\hline \multirow[t]{2}{*}{ B } & 1 & $3641 \pm 14.14^{\mathrm{B}}$ & $0.83 \pm 0.04^{A}$ & $3.66 \pm 0.02^{A}$ & $2409.5 \pm 3.18^{\mathrm{B}}$ & $83.18 \pm 0.25^{\mathrm{B}}$ \\
\hline & 30 & $3540 \pm 56.57^{b}$ & $0.87 \pm 0.03^{a}$ & $4.08 \pm 0.06^{a}$ & $2827.2 \pm 5.09^{b}$ & $101.47 \pm 0.42^{b}$ \\
\hline \multirow[t]{2}{*}{ M } & 1 & $2078 \pm 2.83^{c}$ & $0.80 \pm 0.01^{B}$ & $3.54 \pm 0.03^{B}$ & $1734.1 \pm 2.90^{c}$ & $61.22 \pm 0.31^{c}$ \\
\hline & 30 & $1589 \pm 12.73^{c}$ & $0.84 \pm 0.03^{b}$ & $3.60 \pm 0.00^{b}$ & $2425.0 \pm 3.54^{c}$ & $84.19 \pm 0.14^{c}$ \\
\hline \multirow[t]{2}{*}{$\mathrm{T}$} & 1 & $3876 \pm 8.49^{A}$ & $0.81 \pm 0.01^{\mathrm{AB}}$ & $3.47 \pm 0.01^{\mathrm{BC}}$ & $2977.2 \pm 1.56^{A}$ & $101.31 \pm 0.08^{A}$ \\
\hline & 30 & $3817 \pm 3.54^{\mathrm{a}}$ & $0.85 \pm 0.06^{b}$ & $3.51 \pm 0.01^{\mathrm{e}}$ & $3249.9 \pm 0.28^{a}$ & $118.88 \pm 0.11^{a}$ \\
\hline
\end{tabular}

C: Plant-free Mozzarella cheese, R: Rosemary-added Mozzarella cheese, B: Basil-added Mozzarella cheese, M: Mint-added Mozzarella cheese, T: Turkish Oregano-added Mozzarella cheese

$A, B, C, D, E$ The difference between values with different exponential expressions in the same column was statistically significant $(P<0.05)$ for $1^{\text {st }}$ day of storage

a,b,c,d,eThe difference between values with different exponential expressions in the same column was statistically significant $(P<0.05)$ for $30^{\text {th }}$ day of storage

properties of herby cheese. In the present study, the textural properties of hardness, adhesiveness, springiness, gumminess, and chewiness parameters were analyzed on the $1^{\text {st }}$ and $30^{\text {th }}$ day of storage (Table 5).

In the present study, all cheese samples exhibited the highest hardness on the $1^{\text {st }}$ day of storage. On the $7^{\text {st }}$ day of storage, the mean hardness figures varied between 357.5 and $3876 \mathrm{~g}$ and the highest hardness value was determined in $B$ sample with basil addition. On the $30^{\text {th }}$ day of storage, the hardness of the $R, M, T$ samples were significantly higher $(P<0.05)$. The increase in hardness should be associated with the restriction of the ripening flora by the plants and the biochemical reactions that occurred during storage. Certain studies reported a decrease in hardness of Mozzarella cheese (Ozsunar, 2010; Smith, 2013). Researchers demonstrated that textural characteristics were determined by microbiological growth activity, loss of moisture, enzymatic activity and salt diffusion during ripening in several cheese types (Fox and Wallace, 1997; Puvača et al., 2020). In a study by Metzger et al. (2001), a time-dependent decrease in texture was observed. Yun et al. (1993) attributed the decrease in hardness to the proteolytic activity in Mozzarella cheese after 50 days of storage. In another study, it was determined that the hardness decreased with the increase in moisture (Bhaskaracharya and Shah, 1999).

The adhesiveness of Mozzarella cheese samples varied between 0.79 and 0.81 on the $1^{\text {st }}$ day of storage. The adhesiveness of Mozzarella cheese increased relatively on the $30^{\text {st }}$ day of storage when compared to the $1^{\text {st }}$ day of storage and varied between 0.81 and 0.87 with plant added cheeses. Jeewanthi et al. (2015) determined that the adhesiveness of Mozzarella cheese decreased during storage.

On the $1^{\text {st }}$ day of storage, the springiness of the cheese samples varied between 3.40 and $3.66 \mathrm{~mm}$, while the springiness of the control sample was $3.33 \mathrm{~mm}$ (Table 5). At the end of the storage, the average springiness values for $R, B, M$ and $T$ samples varied between 3.44 and $4.08 \mathrm{~mm}$, while the C sample exhibited $3.52 \mathrm{~mm}$ springiness. In general, it was observed that the differences in ripening time and starter culture viability did not have significant effects on the springiness of the plant added Mozzarella samples. Unlike Jeewanthi et al. (2015), the present study findings demonstrated that the springiness of Mozzarella cheese samples decreased during storage. 
At the end of the storage period, the gumminess of all samples, including the control sample, increased when compared to the $1^{\text {st }}$ day of storage. On the $1^{\text {st }}$ day of storage, the gumminess of the samples varied between 264.6 and 2977.2 g, while on the $30^{\text {th }}$ day of storage, it varied between 302.9 and $3249.9 \mathrm{~g}$. The lowest gumminess was observed in the $\mathrm{R}$ sample, while the highest gumminess was identified in the T sample (Table 5). There were statistically significant differences between the gumminess of all samples $(P<0.05)$. Jeewanthi et al. (2015) determined that the gumminess decreased during storage in Mozzarella cheese.

On the $1^{\text {st }}$ day of storage, the chewiness of the samples varied between $8.93 \mathrm{~mJ}$ ( $\mathrm{R}$ sample) and $101.47 \mathrm{~mJ}$ (B sample). From the $1^{\text {st }}$ to the $30^{\text {th }}$ day of ripening, the chewiness of all samples increased, particularly those of the $\mathrm{B}$ and $\mathrm{M}$ samples (Table 5).

\section{Microstructural properties of the Mozzarella cheese mass}

Transmission electron microscopy (microstructure) analysis was conducted to analyse inner surfaces of Mozzarella cheese samples. The cheese dough contained plants supplement looked smooth and less dense when compared to the outer surface. In the present study, it was determined that, the control group (C) exhibited a more homogeneous structure when compared to the R, B, M and T samples. These samples reflected the heterogeneous structure of the plants where the plants were distributed in the cheese mass (Figure 1). It was suggested that this structural difference was due to the interaction of proteins and fats with soluble polyphenols. In all cheese samples, it was observed that the fat globule structures were impaired, and the casein fragments appeared smaller and much more compact.

In the present study, the impact of the use of various plants in Mozzarella cheese was observed in cheese micrographs. When compared to the control cheese (without plant addition), more complex images were obtained in $\mathrm{R}, \mathrm{B}, \mathrm{M}$ and $\mathrm{T}$ samples. It was observed that especially the addition of basil (B) to Mozzarella cheese led to a more complex appearance when compared to the other samples. Since the curd is cooked during Mozzarella cheese production, it has been reported that due to the impact of the temperature, the gaps in the cheese mass decreased, the

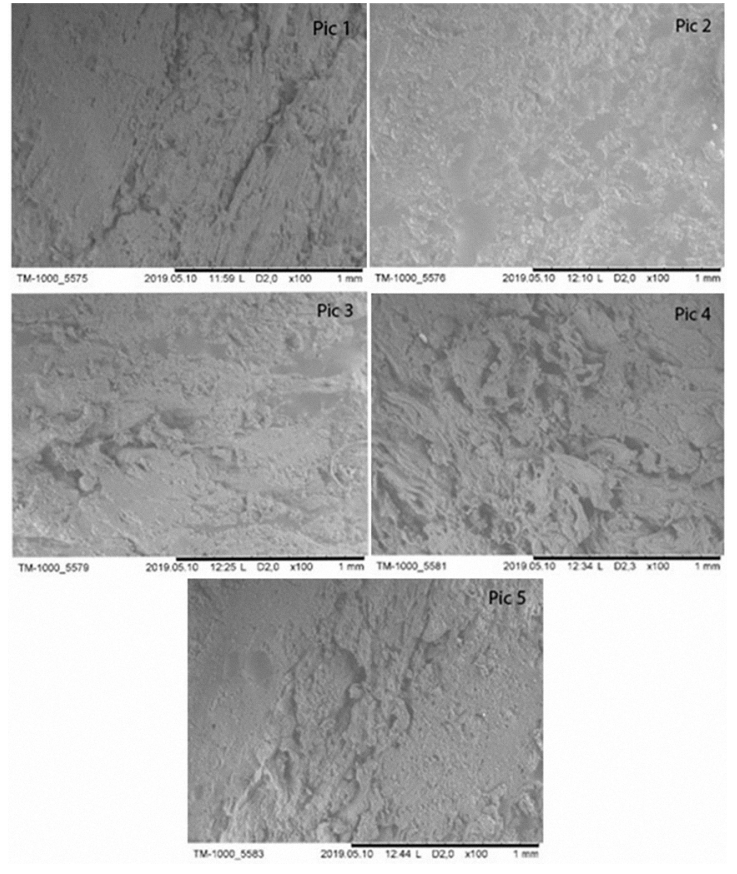

FIGURE 1. Pic 1. Matrix image of the control group Mozzarella cheese; Pic 2. Matrix image of Mozzarella cheese added to rosemary (R); Pic 3. Matrix image of Mozzarella cheese added to basil (B); Pic 4. Matrix image of Mozzarella cheese added to mint (M); Pic 5. Image of Mozzarella cheese matrix added to Turkish Oregano (T)

smoothness of the structure increased, the protein agglomeration became more pronounced due to the effect of scalding, and the hydration water comes out due to the scalding temperature and duration; and thus, more water was removed from the structure (Everett and Auty, 2017; Mehta, 2018). Due to these reasons, the cheese has a harder and firmer structure. The main differences between the images were due to the differences between the added plant species (Figure 1).

\section{Melting ability of Mozzarella cheese}

Mozzarella, one of the best-known Italian cheeses, is frequently used in dishes such as pizza and lasagne, and its melting ability is an important quality criterion. Long, unbroken and melted cheese strings are the characteristics of Mozzarella cheese. Thus, melting and stretching features are frequently investigated in Mozzarella cheese. The flow distance values for Mozzarella cheese with plants, measured with Schreiber melting test and expressed as mm are presented in Table 6. 
TABLE 6. Meltability values (expressed as flow distance $(\mathrm{mm})$ ) of Mozzarella cheeses measured by Scriber Test $(n=2)$

\begin{tabular}{l|l|l|l|l|l}
\hline & \multicolumn{5}{|c}{ Flow distance $(\mathrm{mm})$} \\
\hline Storage days & $\mathrm{C}$ & $\mathrm{R}$ & $\mathrm{B}$ & $\mathrm{M}$ & $\mathrm{T}$ \\
\hline 1 & $5.45 \pm 0.21^{\mathrm{C}}$ & $5.40 \pm 0.14^{\mathrm{C}}$ & $5.60 \pm 0.14^{\mathrm{B}}$ & $5.65 \pm 0.07^{\mathrm{AB}}$ & $5.90 \pm 0.14^{\mathrm{A}}$ \\
\hline 10 & $5.95 \pm 0.21^{\mathrm{AB}}$ & $6.05 \pm 0.21^{\mathrm{A}}$ & $6.05 \pm 0.07^{\mathrm{A}}$ & $5.80 \pm 0.14^{\mathrm{B}}$ & $6.00 \pm 0.14^{\mathrm{A}}$ \\
\hline 20 & $6.25 \pm 0.35^{\mathrm{B}}$ & $6.25 \pm 0.35^{\mathrm{B}}$ & $6.35 \pm 0.21^{\mathrm{A}}$ & $6.05 \pm 0.07^{\mathrm{BC}}$ & $5.85 \pm 0.07^{\mathrm{C}}$ \\
\hline 30 & $5.90 \pm 0.14^{\mathrm{B}}$ & $5.85 \pm 0.21^{\mathrm{C}}$ & $5.90 \pm 0.00^{\mathrm{B}}$ & $6.10 \pm 0.28^{\mathrm{A}}$ & $5.85 \pm 0.07^{\mathrm{C}}$ \\
\hline
\end{tabular}

C: Plant-free Mozzarella cheese, R: Rosemary-added Mozzarella cheese, B: Basil-added Mozzarella cheese, M: Mint-added Mozzarella cheese, T: Turkish Oregano-added Mozzarella cheese

$A, B, C, D, E$ The difference between values with different exponential expressions in the same line was statistically significant $(P<0.05)$

In the current study, it was observed that there was a significant difference between the flow distances of cheese samples measured with the Schreiber test $(P<0.05)$. While the highest flow distance was obtained in the $\mathrm{B}$ sample on the $20^{\text {th }}$ day of storage, the lowest flow distance was detected in the $\mathrm{R}$ sample on the first day of storage. At the beginning of storage, the highest melting ability was determined in the $T$ sample with Turkish Oregano, while the highest was determined in the M sample with mint at the end of storage. Savello et al. (1989) reported that the melting ability of the Mozzarella cheese do not only depend on a single ingredient or a production parameter but on several factors such as casein type, calcium concentration, whey protein content, oil and fat in dry matter, $\mathrm{pH}$, curd scalding temperature and duration. In the present study, there was no significant difference between the melting ability properties of the samples. It could be suggested that the limited proteolysis level and the solubility of the colloidal calcium phosphate in the cheese matrix could have led to similar melting properties. McMahon et al. (1999) reported that the main factors that determine the melting ability of Mozzarella cheese included the interactions between protein fractions, the bulk water entrapped in the protein matrix, and fat content.

\section{Sensory properties of Mozzarella cheese}

Although the main reason for the consumption of functional products are their positive effects on health, the sensory properties of the products also play an important role in daily consumption (Marhanatizade, 2005). Mozzarella cheese is a nutrient characterised by its fresh taste, softness, slightly sour and creeping when heated taste and is preferred due to these properties (IIlupapalayam et al., 2013). Ozcan et al. (2017) reported that the plant species and production methods affected the sensory properties of herby cheese products and traditional methods provide better taste for the consumers. In the present study, Mozzarella cheese samples were analysed for colour, flavour, texture and overall acceptance properties. Sensory evaluation results for the Mozzarella cheese samples with plants were obtained with the sensory evaluation scale and are presented in Figure 2.

The colour and appearance scores of cheese samples are presented in the relevant list. The control group (8.71), the cheese samples with rosemary (8.14) and Turkish Oregano (8.00) were the most preferred groups based on colour and appearance and the lowest scores were observed in the cheese samples with mint (7.85) and Turkish Oregano supplements (7.71). At the end of the ripening period, significant differences were observed between the cheese samples. The review of the statistical analysis results based on the color scores, which were a part of sensory evaluation, demonstrated that the presence of different herbs and the effects of the storage period were significant except for the $30^{\text {th }}$ storage day $(\mathrm{P}<0.05)$.

The statistical analysis of flavour scores demonstrated that the presence of different plants $(P<0.05)$ was significant. The analysis of the flavour scores revealed that the cheese samples with Turkish Oregano and mint exhibited preferable features when compared to the others. The analysis of the flavour scores revealed that the samples with mint 


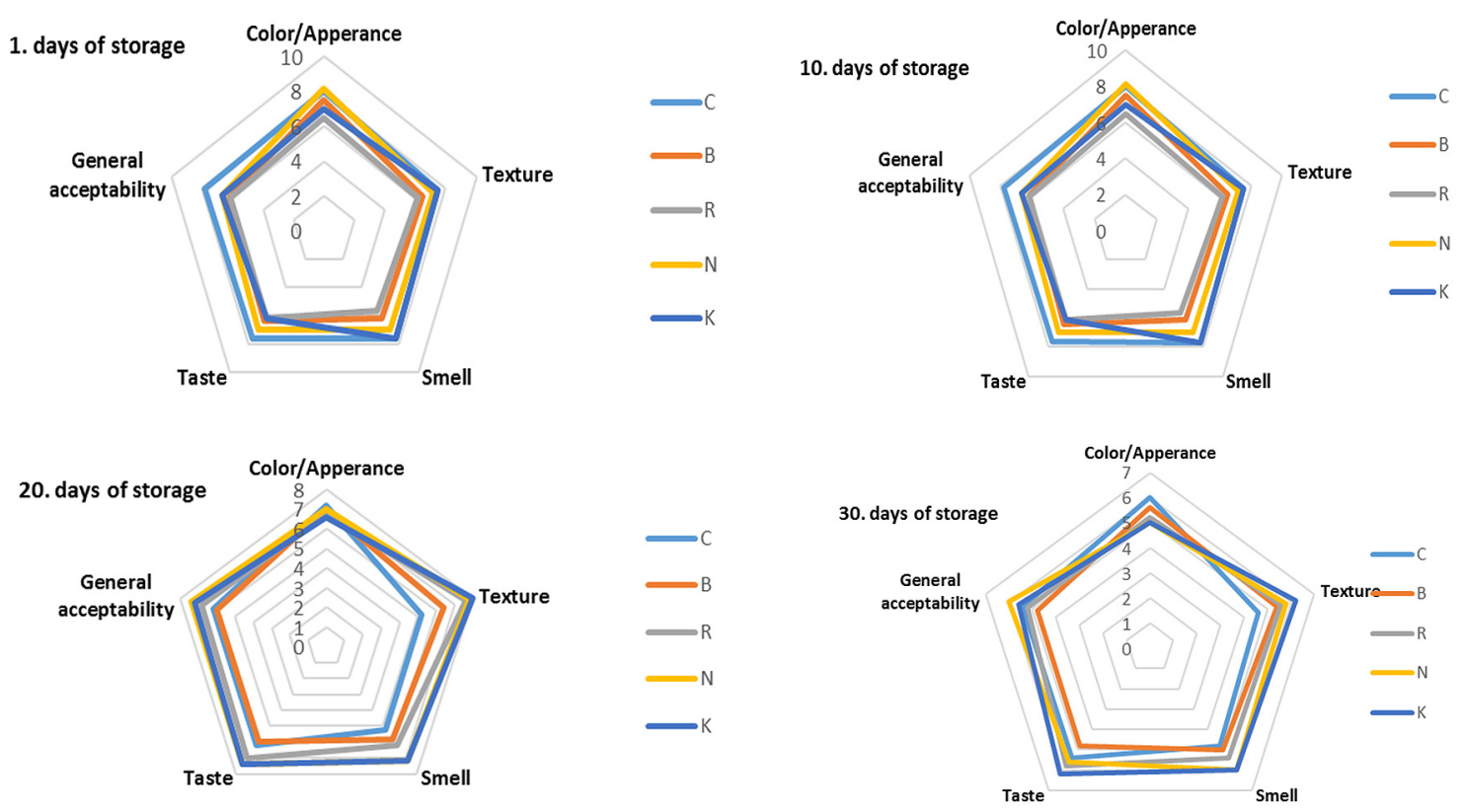

C: Plant-free Mozzarella cheese, B: Rosemary-added Mozzarella cheese, R: Basil-added Mozzarella cheese, N: Mint-added Mozzarella cheese, K: Turkish Oregano-added Mozzarella cheese

FIGURE 2. Sensory scores of Mozzarella cheeses during the storage period

and Turkish Oregano were acceptable. Similar data were reported in a study conducted by Tomar and Akarca (2019).

The analysis of the structure/texture scores (Figure 2) of the cheese samples demonstrated that the structure and texture scores varied between $8.71 \pm 0.49$ and $7.71 \pm 1.60$. At the beginning of storage, the highest structure and texture score was determined for the control group (8.71), and the cheese with Turkish Oregano scored the lowest score (7.71). At the end of storage, the highest value was observed in cheese with Turkish Oregano (6.20) and the lowest score was observed in the control group (4.60). The statistical analysis of the texture scores revealed that the use of different plants was important in cheese production $(P<0.05)$ It was determined that the textural properties of the cheese samples with Turkish Oregano and mint improved in 30 days of storage when compared to other cheese samples (Figure 2).

Odour scores varied between $7.57 \pm 0.97$ and $6.71 \pm 2.21$. As presented in the table, the highest odour value was found in control (7.86) and the lowest values were determined in cheese samples with Turkish Oregano, mint, rosemary and basil. In the cheese matured for 30 days, the highest odour values were observed in cheese samples with Turkish
Oregano and mint and the lowest odour values were observed in the cheese samples with rosemary and the control group. The highest odour value was determined on the $10^{\text {th }}$ day during ripening. The analysis of cheese samples based on odour criteria revealed that the use of different plant addition was important in cheese production $(\mathrm{P}<0.05)$.

General acceptance scores varied between $5.86 \pm 1.25$ and $8.14 \pm 0.90$. Among the fresh cheese products, the highest general acceptability value was determined in the Mozzarella cheese with Turkish Oregano, and the lowest was determined in the cheese with rosemary (5.86). Among the mature cheeses, the highest value was determined in the cheese with mint (8.94) and the lowest value was determined in the cheese with rosemary (7.88). When the statistical analysis of the plant added Mozzarella cheese samples based on all impression scores revealed that the presence of various herbs was significant $(P<0.05)$. Based on the sensory analysis conducted on the $15^{\text {th }}$ day, Akarca (2013) reported that the panellists liked the cheese products more when compared to the first day. In the same study, the sensory analysis conducted on the last day of ripening demonstrated that the taste of the cheese products decreased. Solak (2013) determined that the taste scores of all cheese 
samples decreased at the end of the storage. Similar to the present study, Deveci (2016) developed a novel product by adding different spices to Feta cheese and reported that the cheese with thyme and mint was liked better. Paksoy (2016) reported that cheese with thyme was appreciated among ultra-filtrated cheeses with plant supplements, and the sensory scores increased during storage.

\section{Conclusion}

In the present study, Mozzarella cheese samples were produced with different plant addition (rosemary, Rosmarinus officinalis L.; basil, Ocimum basilicum L.; mint, Mentha piperita L.; Turkish Oregano, Origanum onites L.) and stored in cold $\left(4^{\circ} \mathrm{C}\right)$ for 30 days. Certain physicochemical, textural, microstructural, solubility and sensory properties of the Mozzarella cheese samples were determined. The study findings demonstrated that the Mozzarella cheese with rosemary exhibited high $\mathrm{pH}$ and low titration acidity, while the cheese samples with mint and Turkish Oregano exhibited lower free fatty acid content. The cheese samples with rosemary and Turkish Oregano exhibited higher hardness, and based on microstructure, the cheese samples with rosemary exhibited a more homogeneous microstructure. Since various plant species affect metabolites due to bacterial growth, effects were observed in $\mathrm{pH}$, acidity development and free fatty acid content, and the structural properties of the plants also affected the textural and microstructural properties of the cheese samples. In sensory analysis, Mozzarella cheese samples with Turkish Oregano and mint were appreciated by the panellists during the storage period. In future studies, it is recommended to investigate the product quality parameters after various rates of plant extracts are added to the cheese products.

\section{Acknowledgement}

The present research was sponsored by Ege University Scientific Research Projects Coordination Unit (Project Number: 16-ZRF-015, ID: 1002).

\section{Utjecaj dodatka začinskog bilja na odabrana fizikalno-kemijska, teksturalna, mikrostrukturna i senzorska svojstva te na sposobnost topljenja sira tipa Mozzarella}

\section{Sažetak}

Mozzarella je sir koji se proizvodi gnječenjem sirnog tijesta u vrućoj vodi. Samo tijesto je karakteristične filamentozne strukture te ima dobru sposobnost topljenja i rastezanja. Cilj ovog rada bio je istražiti utjecaj dodatka odabranog začinskog bilja na određena svojstva Mozzarella sira. Ružmarin (Rosmarinus officinalis L.), bosiljak (Ocimum basilicum L.), paprena metvica (Mentha piperita L.) i turski origano (Origanum onites L.) dodani su Mozzarella siru u fazi gnječenja, dok su fizikalno-kemijska, teksturalna, mikrostrukturna i senzorska svojstva te sposobnost topljenja određivani tijekom perioda skladištenja. Kontrolni uzorak sira proizveden je bez dodatka začinskog bilja. Prethodno spomenuti dodaci utjecali su na neka svojstva Mozzarella sira kao što su pH, kiselost, slobodne masne kiseline, tekstura i mikrostrukturna svojstva. Nadalje, uočena je i promjena senzorskih svojstava, pri čemu je pogotovo dodatak turskog origana i paprene metvice uzrokovao bolju prihvatljivost te bolji okus i aromu. Dok su niža pH vrijednost i titracijska kiselost utvrđeni kod sireva s dodatkom ružmarina, najniži udio slobodnih masnih kiselina (ADV) utvrđen je kod sireva s dodatkom paprene metvice. Sirevi s dodatkom ružmarina bili su tvrđi i jednoličnije mikrostrukture, dok su najbolja senzorska svojstva imali sirevi s dodatkom turskog origana i paprene metvice. Zaključno, rezultati ovog istraživanja pokazali su kako se trajnost Mozzarella sira može produljiti dodatkom različitog začinskog bilja zbog povoljnog utjecaja na pH, kiselost i slobodne masne kiseline.

Ključne riječi: Mozzarella, začinskog bilje, mikrostruktura, sposobnost topljenja, svježi sirevi 
1. Abou El-Elia, W.M., El-Neshawy, A. M., Rabie, A.M., Emara, E.A. (1986): An attempt to produce Ras cheese by direct acidification. Food Chemistry 19 (2), 81-91. https://doi.org/10.1016/0308-8146(86)90102-0

2. Aćimović, M., Čabarkapa, I., Cvetković, M., Stanković, J., Kiprovski, B., Gvozdenac, S., Puvača, N. (2019). Cymbopogon citratus (DC.) Staph: Chemical composition, antimicrobial and antioxidant activities, use in medicinal and cosmetic purpose. Journal of Agronomy, Technology and Engineering Management 2 (6), 344-360.

3. Agboola, S.O., Radovanovic-Tesic, M. (2002): Influence of Australian native herbs on the maturation of vacuum-packed cheese. LWT-Food Science and Technology 35 (7), 575-583. https://doi.org/10.1016/S0023-6438(02)90917-5

4. Akarca, G., Caglar, A., Tomar, O. (2016): The Effects spicing on quality of Mozzarella cheese. Mljekarstvo 66 (2), 112-121.

5. Andic, S., Genccelep, H., Kose, S. (2010): Determination of biogenic amines in Herby Cheese. International Journal of Food Properties 13 (6), 1300-1314.

https://doi.org/10.1080/10942910903061869

6. Andreatta, E., Fernandes, A.M., Santos, M.V., Mussarelli, C. Marques, M.C., Oliveira, C.A.F. (2009): Composition, functional properties and sensory characteristics of Mozzarella cheese manufactured from different somatic cell counts in milk. Brazilian Archives of Biology and Technology 52, 1235-1242. https://doi.org/10.1590/S1516-89132009000500022

7. Anonymous (2020): https://www.thespruceeats.com/ what-is-mozzarella-cheese-1807036.

8. A.O.A.C. (1990): Official Methods of Analysis of the AOAC, $15^{\text {th }}$ edn. Methods 932.06, 925.09, 985.29, 923.03. Arlington, VA: Association of Official Analytical Chemists.

9. Ardö, Y. (1999): Evaluating proteolysis by analysing the $\mathrm{N}$ content of cheese fractions in Chemical methods for evaluating proteolysis in cheese maturation (Part 2) Bulletin of the International Dairy Federation 337, 4-10

10. Atanasov, A.G., Waltenberger, B., Pferschy-Wenzig, E-M. (2015): Discovery and resupply of pharmacologically active plant-derived natural products: a review. Biotechnology Advances 33, 1582-1614. https://doi.org/10.1016/j.biotechadv.2015.08.001

11. Bhaskaracharya, R.K., Shah, N.P. (1999): Texture evaluation of commercial Mozzarella cheeses. Australian Journal of Dairy Technology 54, 1-36.

12. Deveci, F. (2016): Investigation of effects on ripening of different types of spices used in White cheese production. University of Ordu Institute for Graduate Studies in Science and Technology Department of Food Engineering, 2016 MSc. Thesis, 98p

13. Everett, D.W., Auty, M.A.E. (2017): Cheese microstructure. P.L.H. McSweeney, P.F. Fox, P.D. Cotter, D.W. Everett (Eds.), Cheese: Chemistry, physics and microbiology (4 $4^{\text {th }}$ ed.), Academic Press, London (2017), p. 549
14. Fasale Abhijeet, B., Patil Vaibhav, S., Bornare, D.T. (2017): Process optimization for Mozzarella cheese from cow and buffalo milk. International Journal of Food and Fermentation Technology 7 (1), 165-173. https://doi.org/10.5958/2277-9396.2017.00018.6

15. Fife, R.L., McMahon, D.J., Oberg, C.J. (1996): Functionality of low fat Mozzarella cheese. Journal of Dairy Science 79, 1903-1910. https://doi.org/10.3168/jds.S0022-0302(96)76559-1

16. Fox, P.F., Wallace, J.M. (1997): Formation of flavor compounds in cheese. Advances in Applied Microbiology 45, 17-85. https://doi.org/10.1016/S0065-2164(08)70261-2

17. Gonzalez, L., Wendorff, W.L., Ingham, B.H., Jaeggi, J.J., Houck, K.B. (2000): Influence of salting procedure on the composition of Muenster type cheese. Journal of Dairy Science 83, 1396-1401. https://doi.org/10.3168/jds.S0022-0302(00)75008-9

18. Hamad, M.N.F., Abdul-Kader, Y.I., El-Metwally, M.M.M. (2017): Mozzarella cheese from recombined cow milk. Indian Journal of Dairy Science 71 (4), 360-367.

19. Helrich, K. (1990). Official Method of Analysis of the AOAC, 15th edn. Rockville, MD: Association of Official Analytical Chemists.

20. IDF (1980): Milk and milk products - Guide to sampling techniques, pt. 4: Provisional International IDF (International Dairy Federation) Standard 50 A: 1980. International Dairy Federation, Brussels (Belgium).

21. International Standard Organization (ISO, 2004): Cheese and processed cheese: determination of the total solids content (ISO 5534). ISO, Genava.

22. International Standard Organization (ISO). (2008). Cheese: determination of fat content: Van Gulik method (ISO 3433). ISO, Genava.

23. Jeewanthi, R.K.C., Lee, N-K., Lee, K.A., Yoon, Y.C., Paik, H-D. (2015): Comparative analysis of improved soy-mozzarella cheese made of ultrafiltrated and partly skimmed soy blends with other mozzarella types. Journal of Food Science and Technology 52, 5172-5179. https://doi.org/10.1007/s13197-014-1542-0

24. Katsiari, M.C., Voutsinas, L.P., Alichanidis, E., Roussis, I.G. (2001): Proteolysis in reduced sodium Kefalograviera cheese made by partial replacement of $\mathrm{NaCl}$ with $\mathrm{KCl}$. Food Chemistry 73, 31-43. https://doi.org/10.1016/S0308-8146(00)00275-2

25. Khajoei Nasab, F., Khosravi, A.R. (2014): Ethnobotanical study of medicinal plants of Sirjan in Kerman Province. Iranian Journal of Ethnopharmacology 154 (1), 190-197. https://doi.org/10.1016/j.jep.2014.04.003

26. Kindstedt, P.S. (1993): Effect of manufacturing factors, composition, and proteolysis on the functional characteristics of Mozzarella cheese. Critical Reviews in Food Science \& Nutrition 33, 167-187. https://doi.org/10.1080/10408399309527618

27. Kirk, R.S., Sawyer, R. (1991): Pearson's Composition Analysis of Food. Addison-Wesley Longman Ltd., Harlow, UK. 
28. Koc, N., Acar, R., Celik, S.A. (2018): Potential of medicinal and aromatic plants in the Central Anatolian steppe rangeland and the necessities. Selcuk Journal of Agricultural and Food Science 2, 212-220. https://doi.org/10.15316/SJAFS.2018.87

29. Kocak, C., Bitlis, A., Gursel, A., Avsar, Y.K. (1996): Effect of added fungal lipase on the ripening of Kashar cheese. Milchwissenschaft 51 (1), 13-17.

30. Kosikowski, F. (1982): Cheese and fermented milks, $2^{\text {nd }}$ Ed., Edwards Broth. Inc. Ann. Arbor., Michigan.

31. Mehta, B.M. (2018). Microstructure of Cheese Products, In: Microstructure of Dairy Products, Ed(s): M.M. AbdelRahman El- Bakry, A. Sanchez, B. Mehta, pages: 127-144. https://doi.org/10.1002/9781118964194.ch7

32. Metzger, L.E., Barbano, D.M., Kindstedt, P.S. (2001): Effect of milk preacidification on low fat Mozzarella cheese: II. Chemical and functional properties during storage. Journal of Dairy Science 84, 1348-1356. https://doi.org/10.3168/jds.S0022-0302(01)70165-8

33. Mustafa, G., Arif1, R, Atta, A., Sharif, S., Jamil, A. (2017): Bioactive compounds from medicinal plants and their importance in drug discovery in Pakistan. Matrix Science in Pharmacology 1 (1), 17-26. https://doi.org/10.26480/msp.01.2017.17.26

34. Omar, M.M., El-Zayat, A.I. (1986): Ripening changes of Kashkaval cheese made from cow's milk. Food Chemistry 22, 83-94. https://doi.org/10.1016/0308-8146(86)90027-0

35. Ozcan, T., Yilmaz-Ersan, L., Akpinar-Bayizit, A. (2017). Textural properties of Herby cheese. International Journal of Food Engineering 3 (1), 23-28. https://doi.org/10.18178/ijfe.3.1.23-28

36. Ozsunar, A., Demirci, M. (2010): The effect of mixture with water buffalo and cow milk to Mozzarella like cheese in physicochemical properties and aroma profile. Namık Kemal University, Graduate School of Natural and Applied Sciences Main Science Division of Food Enginnering, PhD Thesis, 87p, Tekirdağ, Turkey.

37. Paksoy, G. (2016): Effects of some spices on quality of ultrafiltered white cheese. MSc. Thesis, Namık Kemal University, Graduate School of Natural and Applied Sciences, Department of Food Engineering, Tekirdag-Turkey, 63 pages.

38. Park, J., Rosenau, J.R., Peleg, M. (1984): Comparison of four procedures of Cheese meltability evaluation. Journal of Food Science 49, 1158-1162. https://doi.org/10.1111/j.1365-2621.1984.tb10417.x

39. Puvača, N., Pelić, D.L., Tomić, V., Radišić, R., Milanović, S., Soleša, D., Budakov, D., Cara, M., Bursić, V., Petrović, A., Vuković, G., Pelić, M., Konstantinović, B., Carić, M. (2020): Antimicrobial efficiency of medicinal plants and their influence on cheeses quality. Mljekarstvo 70 (1), 3-12. https://doi.org/10.15567/mljekarstvo.2020.0102

40. Renner, E. (1993): Nutritional aspects of cheese. ( $2^{\text {nd }}$ ed) P.F. Fox (Ed.), Cheese: Chemistry, Physics and Microbiology, Vol.I, Chapman and Hall, New York, NY. https://doi.org/10.1007/978-1-4615-2650-6_15

41. Rizqiati, H., Nurwantora, S.M., Febrisiantosa, A. (2016): Characteristics of Mozzarella cheese made from Pampangan buffalo in South Sumatera Indonesia. Applied Research Journal 2 (7), 301-306.
42. Sahan, N., Yasar, K., Hayaloglu, A.A., Karaca, O.B., Kaya, A. (2008): Influence of fat replacers on chemical composition, proteolysis texture profiles, meltability and sensory properties of low-fat Kashar cheese. Journal of Dairy Research 75, 1-7. https://doi.org/10.1017/S0022029907002786

43. Scott, R. (1986): Cheesemaking Practice. Elsevier Applied Science Publishers, London.

44. Sezen, I., Demircan, N., Sezen Karaoglan, E. (2018): Use of medicinal and aromatic plants naturally growing in Erzurum city in landscape architecture. Journal of Architecture Sciences and Applications 3 (2), 81-88. https://doi.org/10.30785/mbud.457781

45. Sipahioglu, O., Alvarez, V.B., Salano-Lopez, C. (1999): Structure, physicochemical and sensory properties of Feta cheese made tapioca, starch and lecithin as fat mimetics. International Dairy Journal 9, 783-789. https://doi.org/10.1016/S0958-6946(99)00150-8

46. Smith, J.R. (2013): Assessment of structure and component mobility within Mozzarella cheese: a thesis presented in partial fulfilment of the requirements for the degree of Doctor of Philosophy (PhD) in Food Technology at Massey University, Manawatu campus, New Zealand

47. Stevens, A., Shah, N.P. (2002): Textural and melting properties of Mozzrella cheese made with fat replacers. Milchwissenschaft 57 (7), 387-390.

48. Tunick, M.H., Shieh, J.J. (1995): Rheology of reduced-fat Mozzarella. E.L. Malin, M.H. Tunick (Eds.), Chemistry of Structure-Function Relationships in Cheese, Plenum Press, Sydney, 7-19. https://doi.org/10.1007/978-1-4615-1913-3_2

49. Walstra, P., Geurts, T.J., Noomen, A., Jellema, A., Boekel, M.A.J.S. van. (1999): Dairy Technology: Principles of Milk Properties and Processes. Marcel Dekker, New York. https://doi.org/10.1201/9780824746414

50. Walter, B., Schmid, A., Steber, R., Wermüller, K. (2008): Cheese in nutrition and health. Dairy Science and Technology 88 (4-5), 389-405. https://doi.org/10.1051/dst:2008012

51. Wang, H.H., Sun, D.W. (2002): Correlation between cheese meltability determined with a computer vision method and with Arnott and Schreiber Tests. Journal of Food Science 67(2), 745-749. https://doi.org/10.1111/j.1365-2621.2002.tb10670.x

52. Wichchukit, S., O'Mahony, M. (2015): The 9-point hedonic scale and hedonic ranking in food science: Some reappraisals and alternatives. Journal of the Science of Food and Agriculture 95 (11), 2167-2170. https://doi.org/10.1002/jsfa.6993

53. Yasar, K. (1999): The Effect of different treatments, applied during production of vakuum packaged kashar cheese, on various properties of cheese. Trakya University, Institute for Graduate Studies in Science and Technology Department of Food Engineering, MSc. Thesis, Tekirdag, 98p.

54. Yaygin, H., Dabiri, K. (1989): Researches on the properties of Kashar cheeses made with cows, sheep and goat milk and matured at different temperatures. Journal of Agriculture Faculty of Ege University 26 (1), 333-346. 